\title{
Revisiting Grey Street: The Grey Street Writers Trail in the Context of Urban Regeneration
}

\author{
Bettina Pahlen \\ Lindy Stiebel
}

\section{Abstract}

This paper emerges from joint research by scholars in South Africa and Germany on a literary trail devised in 2006 by the research project KwaZuluNatal Literary Tourism. This urban trail, set in a historically Indian-occupied area of Durban, highlights writers who lived in and wrote about it. Coinciding with the tenth anniversary of the Grey Street Writers' Trail in 2015, the literary trail was the focus of an MA dissertation by Bettina Pahlen on the relationship between the literature trail and ongoing urban renewal activity in the quarter.

The research suggests that the Grey Street Writers trail represents a narrative of what trail designers, guides and authors consider meaningful about a place. Participant's engagement with this trail narrative shows its potential to change the perception of the area under regeneration. Informed by the work of Michel de Certeau (walking the city), Hubert Zapf (literature as cultural ecology), Throgmorton (storytelling in urban planning) and Edward Relph (placemaking, sense of place), this paper investigates factors limiting the trail's contribution to urban regeneration in the Casbah. The questions asked by this paper is first, how the literary trail draws on and is impacted by experiences of urban renewal, and secondly, how the influence of the literary trail narrative on trail participants is limited by design and modified during implementation.

Keywords: cultural heritage, literary trail, urban renewal, Grey Street, Durban 


\section{Revisiting Grey Street}

This paper draws on research led by Lindy Stiebel at KZN Literary Tourism and field research done by Bettina Pahlen between June and August 2015 for a Masters thesis (MA Urban Culture, Society and Space) at the University of Duisburg-Essen on the Grey Street Writers trail in Durban, South Africa. This literary heritage trail (see http://www.literarytourism.co.za) was set up by the KZN Literary Tourism ${ }^{1}$ research project in 2006 . Research on literary heritage trails, as a transdisciplinary area of study, draws on theory from the fields of literary and cultural studies, urban sociology, urban design, social psychology, planning, architecture, archaeology, history and philosophy. The research done may inform the development of participatory spatial knowledge models, community building, placemaking, urban regeneration and tourism.

\section{Literary Trails as Planning Narratives and their Meaning for Regeneration Efforts}

The purpose of a process of structured viewing in urban planning is the creation of a meaningful vision of how a place could be in the future (cf. Throgmorton

${ }^{1}$ KZN Literary Tourism is an academic research project led, since 2002, by Lindy Stiebel, Professor emeritus within the English Department of the University of KwaZulu-Natal. Receiving a five-year grant from the National Research Foundation, the project's objectives were to create a database of writers, to produce a 'literary tourist map of the province' and 'documentary films on selected, representative writers aimed at literature students and literary tourists alike' (Stiebel 2004). The result was a website on which the research database was presented and linked to an interactive map. At the time of writing, KZN Literary Tourism continues to be run for the purpose of academic research (cf. Interview Stiebel L. 2015) with the various trails running on request. The KZN Literary Tourism project remains an academic research project and continues to provide a platform for research on writers and literary trails in KwaZulu-Natal. In the recent past, the Grey Street Writers trail was run as part of this project (cf. interview Stiebel), mainly for University of KwaZulu-Natal students studying literary tourism, and also for adult education groups, such as the Jewish Adult Education group Limmud, for small conference groups and occasional tourists who find the tour online. 
2003, 127). The planning story is only successful as far as elements and argumentation of the proposal resonate with stakeholders' perceptions. Allowing distinct points of view to inform the planning story increases the chances that potential dissonances will be within limits of what is considered acceptable deviation from the norm. The vision therefore should be informed by a range of perspectives for it to be acceptable to stakeholders. Planners

have to adopt distinct points of view and draw upon the imagery and rhythm of language [in combination with planning tools] to express a preferred attitude toward the situation and its characters (Ibid).

As a type of 'planning story', a literary trail can be said to 'unavoidably shape the [stakeholder]'s attention' (Throgmorton 2003: 127) in a normative way. The initial process of selection in the design and implementation of the literary trails a normative potential, as much as the perspectives informing the 'literary trail' or 'planning story' as presented and perceived on the ground. Literary trails can contribute to generative development plans in the process of formulating a vision of what should be regenerated, providing a vision at least partially based on what has been perceived by trail designers and authors and guides (themselves partially reflecting sentiments of their social networks) as characteristic, meaningful and valuable about the Grey Street Casbah.

In general, three main perspectives, shaped by the type of research done and methodology, inform the trail's representation of the Grey Street Casbah. First, the trail is a result of what the designers of the trail considered to be meaningful in literature connected to the area. Second, the excerpts of literature presented on the Grey Street Writers trail draw attention to what makes places meaningful in the eyes of the writers. Third, the delivery of the trail design by the trail guide gives further insight into what is considered meaningful, taking into account trail design, client's interests and the daily changing urban context.

However, even the resulting imaginary shaped by these three dominant perspectives may not necessarily be the imaginary perceived by individual participants. Prior knowledge and the degree of resonance between trail and personal imaginaries and acceptability of dissonances. Prior knowledge may be drawn, for example, from encyclopaedias, pictures, books, newspapers or hearsay, which is remembered during the experience of a site visit. The immediacy of street life perceived and the narratives are filtered through and 
compared with the existing layers of webs of previously accumulated and interlinked information. The purpose of this filtering process on the part of the participant is, however, to confirm prior knowledge, and not necessarily reconfigure it (cf. Mann 1997).

The success of the 'planning story' of the Grey Street Writers trail strongly depends on the ability of the trail to mediate, to explain and to guide perception and interpretation of experiences with regard to negotiating the strength and number of dissonances between the prior knowledge of participants and the newly perceived narrative of the trail. The acceptability of new imaginaries is possibly increased further by allowing for the opportunity to validate stories and gain experience through interaction with and exposure to the environment quasi independently. Dissonances within the realm of acceptability have the potential to modify the participant's preformed imaginaries of a place to a certain extent; to 'push the envelope'.

Urban culture may be defined as the,

artistic, performative, literary or medial cultural expression, with a use of semiotic resources in urban contexts [...] that can be seen to react to key urban challenges but also actively [... shapes] perceptions and thus [can also be seen as] socially productive (Gurr in Szczekall 2010: 245).

This 'socially productive' momentum can be used as a resource to inform plans of action by architects, urban designers, and the community of stakeholders of a place. To analyse the effect and structure of this expression of urban culture - the guided, area-based literary trail - the concept of mediacy provides a suitable framework to analyse the impact of constituent parameters of the Grey Street Writers trail on participants. The theoretical framework is put to work on the literary trail and how it may modify the perception of the Casbah.

\section{Grey Street Writers amid Regeneration Projects}

The Warwick Junction Precinct (white circle), in which the Grey Street Casbah (white polygon) is located continues to be generally perceived as a territory lacking safety despite ongoing regeneration efforts since the end of apartheid, when laws prohibiting free movement of people through urban spaces were 
abolished. This structural and legal change created great uncertainty in the population and the municipality as to people's right to access city spaces they had previously frequented, or had been prohibited from entering, such as the markets around Durban's central business district. Architect Jonathan Edkins recalls 'There was a great sense of "Do I belong in this space, is it for me? [...] Am I allowed to use it? Is it safe?"' (Interview Edkins 2015). Socio-economic spaces (street stalls and shops) became contested, initially violently as the municipality grappled with the question of how to approach their management differently. Since then, suitable approaches were developed (cf. Interview Edkins, J. 2015) and the historic buildings, streets, pavements and markets largely re-appropriated by symbiotic networks of 'informal' (e.g. street vendors, cardboard collectors, car washers, trolley pushers) and 'formal' economies (e.g. shop owners), which contextualize the Grey Street Writers trail.
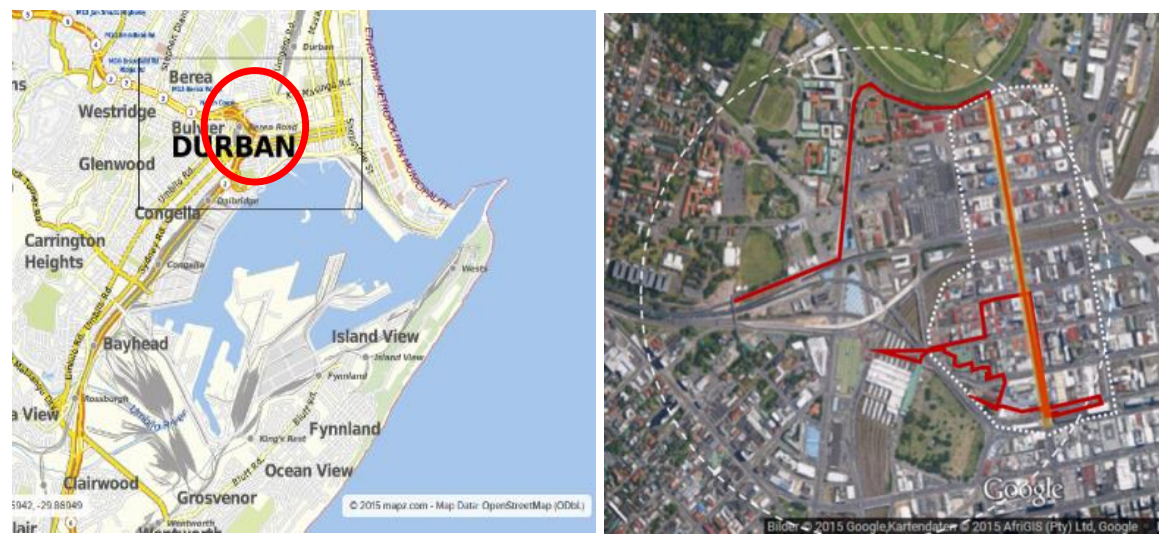

The Grey Street Writers ${ }^{2}$ literary trail (red line: the path taken during the examined trail run), is the first of the walking trails created by KZN Literary Tourism. In terms of location for an area-based walking trail, research indicated that

${ }^{2}$ Created in cooperation with Niall McNulty, for some years Stiebel's research assistant. It was the first area-based walking trail of a series of area-based literary trails. 
Grey Street was a good [choice] because, it's walkable, and there is a whole cluster of writers that were associated historically with that area (Interview Stiebel 2015).

When planning the trail KZN Literary Tourism

demarcated quite a tight space, taking in much of the main social and political sites $[\ldots]$, certainly those that are linked to our writers (Ibid).

Grey Street (yellow line on map), officially renamed Dr. Yusuf Dadoo Street, lies within the 'Warwick Junction Precinct' (Rosenberg et al. 2013, red and white circles on map) and has historically strong connections to other streets of this precinct. Commonly, the name 'Grey Street' is seen to identify an entire area 'much bigger than just the main street that runs through it' (Interview Stiebel 2015), and is referred to as the Grey Street Casbah (cf. Interviews Madressa Arcade 2015, white dotted polygon on map).

The literary trail is constructed around the engagement of selected writers with experiences of living in the Casbah. It features selected works by Phyllis Naidoo, Dr Goonam, Fatima Meer, Aziz Hassim, Mariam Akabor, Ravi Govender and Imraan Coovadia, who write based on socio-economic realities, as well as of experiences of resistance movements against socio-economic segregation, indentured labour and apartheid laws. A major focus of ongoing regeneration efforts in the precinct is the informal service and retail sector with its strategic transport and shopping hub along Warwick Avenue, reaching into the neighbouring Grey Street, Beatrice Street and AK Mansion areas in the east, the Duchene and the DUT campus area in the west. By providing structured insight into aspects of an area under regeneration and deemed meaningful in the past and present, the Grey Street Writers trail carries the potential to mediate and change preconceived urban imaginaries associated with this area, making the trail potentially relevant to regeneration efforts.

\section{Post-apartheid Urban Regeneration of Grey Street and Sense of Place}

The contemporary pattern of urban regeneration in Durban's Central Business District started with the building of the International Convention Centre in the 
early nineties. The experience gathered there in community-led generative planning led to the founding of ITRUMP and subsequently informed work being done on the 'Warwick, Grey Street and Albert Park' area. The approach proved very successful for Warwick. However, efforts in Grey Street and Albert Park were hampered by several post-apartheid infrastructure developments, as well as changes in political leadership and the style of urban management of the municipality around 2005 in the lead up to the 2010 World Cup. Edkins explains that 'Grey Street was seen as part of the [same designated planning] area, but it has a distinct character. [...] Experiencing Grey Street was not the same as the experience around [Warwick] station' (Interview Edkins 2015), reasons for which can be found in the Casbah's history.

The Indian community in Durban, dating back to the British system of indentured labour, invested substantial amounts of money and effort into building educational facilities to serve their population on the north-western side of the railway tracks (cf. Rosenberg et al. 2013, 35). In time, the Grey Street Casbah, a result of racialized spatial constraints, first of legalized segregation and then systematic apartheid policy,

was the most concentrated Indian commercial area in South Africa. A strong relationship between the more mixed-residential and businesscentred eastern side of the railway tracks (Grey Street and Beatrice Street areas, also known as the Casbah) and the more residential and educational western side of the railway tracks, was literally built, connected via the markets (cf. Rosenberg et al. 2013: 130-156).

In the 1960s, the Grey Street Casbah was recognised to lie within the borders of Albert Street, the Railways Reserve, West Street, Broad Street, Pine Street, Grey Street, Commercial Road, Warwick Avenue and Mitchell Road (cf. Rosenberg et al. 2013: 35).

Of the 418 properties in this area, 95\% were Indian-owned and 97 percent Indian occupied, comprising 130 light industries, 90 wholesalers, 30 restaurants, six luxury cinemas, 125 professionals (mostly doctors and attorneys), a Technical College, churches, a temple, mosques and the Victoria Street Market with 300 Indian stalls (Rosenberg et al. 2013: 35). 
Lying at its heart,

The old, traditional Grey Street area was characterized by jewellery makers, goldsmiths living above their businesses [in] very small buildings and offices, very high value. Making good incomes. A little enclave the way the cities probably should work (Interview Edkins 2015).

In 1969 the Department of Planning began to consider re-zoning the area to 'White', a process which would last twenty years. While these plans met with broad resistance, they had already substantially changed the character of the area. The long period of uncertainty had severely inhibited investments in infrastructure maintenance and probably initiated the slow deterioration of the area. In 1973 the area was still designated Indian, but for commercial use only, meaning ' 12000 residents had to vacate the area' (Rosenberg et al. 2013: 35). The disintegration accelerated in the early nineties, when substantial 'changes to the road system' (Interview Edkins 2015) were made (cf. Rosenberg et al. 2013: 35). The construction of an additional bridge, a widening of streets making a large number of them one-way, and 'the introduction of the bus depots in that area [meant] streets which had been peopled streets [were not trafficked as much as they had been before] while others were trafficked to such an extent [that the remaining] little enclaves couldn't survive. [...] People actually didn't want to live in that kind of environment' (Interview Edkins 2015). Many people who had the money moved to other areas of Durban (cf. Ibid). The integrity of that environment depended on 'very delicate relationships between people, their work, their modes of transport, the street, the schools, all of those things which were there. Once you pull one of them out there's an imbalance' (Ibid).

Prior to the FIFA World Cup 2010, the deteriorating precinct became the target of commercial and political speculation that would further impact upon the informal sector, the urban heritage of the area, as well as housing through plans for a new mall on the site of the Early Morning Market and Berea Station, latter of which borders on the Grey Street Casbah and can be seen on the trail from a distance. 'The development of this new mall [...was] pushed hard by the city manager. [...] It was projected that this was for the better of the people on the ground' (Interview Edkins 2015). The strategy involved '[...] traders in the Early Morning Market [...] being characterized as 'Indian' and a 
minority who were running the show, stopping progress which would benefit the street traders and commuters [..., subjecting [black traders] to poverty' (Ibid). The picture was polemical, oversimplified, but politically useful. Extensive resistance by businesses, market vendors, architects and urban planners alike led to the suspension of plans for the mall.

Currently, a new plan for a mall in the area bears an acute problem, identified by Edkins, in that it 'affects the Badsha Peer area [...] the whole roofed area' (Interview Edkins 2015). The Badsha Peer shrine is dedicated to Durban's most important Islamic saint and is located on Durban's oldest cemetery, across the road from the Mosque and the Cathedral next to Berea Station. The roofed space between the station and the cemetery where the shrine is located,

used to be a road. Richard [Dobson (ITRUMP; Asiye eTafuleni)] was responsible for the roofing [... and for the] negotiations which led to it being shared: Once a year it's cleared for the ceremony and the rest of the year they use the area to benefit the local population [as a marketplace] (Ibid).

While everything is being done by the architect involved to accommodate the existing system of formal and informal economies, Edkins fears that once the new plans for the mall become public, there will be resistance. Another factor inhibiting regeneration efforts is the lack of potent heritage protection laws protecting areas and buildings of heritage value: the constellation of decaying buildings in the inner city and the general shortage of affordable housing is resulting in unused or condemned buildings are occupied illegally (cf. Interview Edkins 2015). Finally, the northern edge of Durban's bay will be regenerated based on ecological principles with the aim of reconnecting the inner city with the bay, and bringing the beachfront into the inner city (cf. Interview Edkins 2015), which is hoped to encourage people to go shopping in the Casbah.

Within this context of contestation, memories of the quality of life before and during these profound changes to society and the urban infrastructure, together with experiences of contesting approaches to regeneration (infrastructure-led versus socio-ecological) may explain the number of writers who have chosen to write nostalgically (but also critically) about the 1950s-60s Grey Street (Hassim \& Govender), or a younger 
generation of authors (Akabor \& Coovadia) that has more recently tried to trace the remaining elements of that earlier time in today's setting. Similarly, the history and spirit of resistance movements that characterized the area inspired another set of authors to write less nostalgic political non-fiction (Meer \& Naidoo), which is of relevance again in the midst of current challenges to the regenerating socio-economic fabric of the Casbah.

\section{Urban Regeneration and the Development of a Critical Sense of Place}

The greatest potential for the Grey Street area, according to Architect Jonathan Edkins, is to regenerate is as an area of character, to try and build on the current potential of the lanes, the small spaces and markets which give it a real sense of place. Sense of place is crucial for understanding how literary trails carry the potential to transform perceptions and contribute to urban regeneration by addressing perceived safety concerns associated with visiting the Casbah. According to Edward Relph, sense of place is commonly understood to be 'an intersubjective feeling, an innate faculty [for distinguishing and appreciating places ... that pulls together and arranges information from the senses of sight, smell, touch, hearing, and also calls on memory and imagination... and] 'is possessed in some degree by everyone and recognizable to others who live elsewhere' (Relph, http://www.placeness.com/sense-of-place-an-overview/). This innate ability to sense place,

can be enhanced through critical attention to what makes places distinctive, how they have changed and how they might be changed. As a critical approach to an appreciation of the distinctive personalities of different environments, the critical enhancement of sense of place is an aspect of education in Geography, Architecture, Landscape Architecture, and Urban Design (Relph http://www.placeness.com/ sense-of-place-an-overview/).

A literary trail is one of many ways to draw attention to the distinctiveness of the Casbah as it is and was, the progress made in regenerating the area, providing insight into challenges being tackled, thereby contributing to balancing perceptions of the place. 
The process of altering a bad reputation of an area for the better is a slow one. It generally demands that many people are given the opportunity to repeatedly gather positive experiences in interaction with people and places within the regenerating context (cf. Mann 1997: 195). This includes the opportunity to reflect upon these experiences within the context, as part of a group, with added information and a professional guide (cf. Ibid 191-198). This allows for engagement with the environment necessary to enhance people's ability to develop a more critical sense place (cf. Relph) through a relational exploration of the Casbah (cf. De Certeau). Taking people into regenerating areas and walking, sitting and talking with people without occasioning negative experiences is a first, often most sensitive, step in the process. A literary trail, such as the examined Grey Street Writers trail, could be a way to overcome the initial hurdle to addressing the negative attitudes towards the Casbah.

Prerequisites for such a literary trail are already existing: a relatively safe regenerating urban environment, a body of literature connected to the place, research on the connection between place, literature, authors and history, trained guides, as well as tourists, such as literary heritage enthusiasts, or simply the curious. The group setting potentially decreases apprehensions felt, creating a sense of group cohesion and 'safety in numbers'. In a group containing people accustomed to the environment, as well as those new to it as will be shown in the trail run examined in this article - the more familiar contribute to the mediation done by the tour guide and moderate spontaneous reactions to unfamiliar impressions by explanation and example. The social status and reputation of the guide within the community (or shopping precinct) being toured is of vital to the success of the trail, as this influences the interaction with shop-keepers and street vendors, as much as the degree to which the trail's presence is at least tolerated by the people living and working in the Casbah.

\section{Literary Functions of the Grey Street Writers Trail}

The Grey Street Writers trail provides an opportunity to visit a place linked to the Indian diasporic experience, using literature as a lens. The trail,

in essence links such sites together and is inevitably a construct: in 
effect a strung-together narrative linking places sequentially in an environment which may in fact have had a far less seamless coexistence with the writer (Stiebel 2010: 6).

Making reference to Robinson and Andersen, there is 'a desire in trails' for

a sequence that makes 'sense': [T]the tourist trail gives order (often an artificial order) to a sequence of locations, which are selected for inclusion in the trail because together they will make sense, form a whole (Ibid).

The construction of the 'sense' or meaningfulness of a literary trail results from a planning process that entails the identification and construction of links between writers, writings and place - physically and on the level of content.

Planned stops along the trail, filled with historical or literary input, combined with the sensory input of walking or driving inform and guide the process. As observed during the trail run, a group of trail participants provides the opportunity to talk or think about events with the guide and other members of the group as they are experienced, thereby immediately gaining a more nuanced understanding of what is perceived. Understanding generally increases familiarity, sharpens the ability to interpret the actions and events in the urban surroundings, thus providing visitors the opportunity to gain a new sense of orientation and belonging in the city. In this respect, the focus on the preservation of authenticity is a strength of the Grey Street Writers trail, enabling visitors the chance to compare the narrated sense of a place with what they experience in the present.

This process can be likened to an urban designer's processes of analysis and synthesis: drawing connections between fragments of knowledge gleaned from interviews, workshops, visits to archives, as much as locations marked on a map. One category of information per map layer structures the information gathered. Superimposing layers in any particular sequence allows the planner to experiment with a variety of viewing patterns and thus become aware of specific connections between layers that need to be viewed in a certain sequence and combination to make sense. This so-called 'structured viewing' which the trail then exposes the participants to, enables a purposeful association of meaningful elements. This part of the planning process stands at the beginning of the creation of a literary trail and may be termed 
'emplotment', a constitutive part of placemaking (cf. Project for Public Spaces), if one understands 'place' as 'space to which meaning has been attached' (Carter 1994). The underlying argumentative reasoning for a certain sequence may be referred to as the planner's 'story' (cf. Throgmorton 2003: 127; Meyer 2008: 60). Both are constitutive parts of a planner's narrative, the narrative here being the Grey Street Writers trail.

\section{Literary Trail Mediacy and its Transformative Potential}

Drawing on the concepts of space and Michel de Certeau's relational understanding of the city and the agency of people in the concept of 'strategies' and 'tactics', Gurr proposes the 'relational category of mediacy as an additional heuristic tool for the systematization of urban cultural practices' (Gurr in Szczekall 2010: 246).

Among the many possible factors influencing mediacy, the mode of transport chosen to physically move from one place to the next along the trail is the most powerful. The experience of driving a car through a part of the city is very different from walking the route. The car are shields from the elements. Exposure to sensory stimulants multiplies as soon as one steps out of the car. The speed at which you move through space impacts the amount of information your senses can access. Alexander Schmidt mentions that 'When walking, a substantially greater amount of minute details are perceived, compared to travelling at $25 \mathrm{~km} / \mathrm{h}$, with the bicycle or $50 \mathrm{~km} / \mathrm{h}$ or $100 \mathrm{~km} / \mathrm{h}$ with the car' (Bucksch \& Schneider 2014: 304-305, own translation).

Just as driving, walking is a 'process of appropriation of the topographical system' (Bridge \& Watson 2002: 386). If one understands place, as defined by Carter et al. (1993: xii), as 'space to which meaning has been ascribed', then walking is a relational act of physically ascribing meaning to space. De Certeau (1980), speaks of walking as 'a space of enunciation' (in Bridge and Watson (2002: 387) a term which allows for the articulation of meaning based on spatial relations between walker and physical infrastructure, making walking a 'spatial acting-out of the place' (Ibid). As a walker, you introduce yourself as a new spatial point of reference and as one moves, one constantly reconfigures the properties and dimensions. This 'implies [logical/causal] relations among differentiated positions, that is, among pragmatic 'contracts' in the form of movements' (Bridge \& Watson 2002: 386- 
387). Walking is thus understood to be a creative act, changing the perceived configuration of the perceived meaning or 'sense' of the place. This relational understanding of space and place is key to the concept of mediacy (cf. Gurr 2010) and placemaking.

Walkability refers to the extent to which this space can be appropriated or 'articulated' by any given pedestrian. Immediately obvious is that higher levels of mediacy can be achieved by car than on foot, but that there is a level of intersection between the highest levels of mediacy on foot and the lowest levels of mediacy by car. Regarding elevation, at the Nicol Square parkade where the trail has a stop, participants were not at street level, but physically removed by elevation from direct immersion in street-life. A category for distance above ground thus needed to be introduced, since the distancing effect of elevation, which is similar to that in the car, is of a distinctly different quality due to the changed vantage point.

Important to note is that there is a continuum between mediacy and immediacy, and that these levels change from person to person depending on prior knowledge and general interest in literature and history compared to street life. Further modifying factors may be the quality of delivery of literature readings, choice and length of readings. Due to the higher level of symbolism of literary excerpts, the level of defamiliarization is higher that with reports of historical facts. A high level of mental mediacy might be achieved by perceiving a story that allows the audience to imagine, to create pictures of actions and events being narrated on the basis of preformed experiences and knowledge.

Mediacy is described as the level of direct 'confrontation of geometrically exact and technologically functional forms with the human body and to re-semanticize and re-perspectivize the urban space through the contrast of living and 'non-living' built environment' (cf. Gurr 2010: 370, own translation), as done, for example, with specific urban sports such as '[p]arcours' (Ibid 370). These make unmitigated use of physical structures, physically confront, question and probe the properties, possibilities and boundaries of architecture, which for our purposes represents a mediacy of zero.

The level of mediacy on the trail generally does not drop to this level because walking and interaction on the trail implies the introduction of intermediaries (physical, cognitive), which interferes with the direct exposure to the environment and can be achieved through increasing the physical 
distance (proximity, exposure modified by mode of transport), cognitive input (readings, interactions within the group and with people outside) distracting from the individual sensory perception of the environment. A guide to the abbreviations and its effect of the mediacy graph of the trail is shown by the tables below ${ }^{3}$.

\begin{tabular}{|l|l|r|}
\hline TIE-Code & Description & M-Value \\
\hline FNG & foot-none-ground & 1 \\
\hline FNA & foot-none-above & 2 \\
\hline FGG & foot-general-ground & 2 \\
\hline FGA & foot-general-above & 3 \\
\hline FRG & foot-reading-ground & 3 \\
\hline .FRA & foot-reading-above & 4 \\
\hline BNG & bicycle-none-ground & 2 \\
\hline BNA & bicycle-none-above & 3 \\
\hline BGG & bicycle-general-ground & 3 \\
\hline BGA & bicycle-general-above & 4 \\
\hline BRG & bicycle-reading-ground & 4 \\
\hline BRA & bicycle-reading-above & 5 \\
\hline CNG & car-none-ground & 3 \\
\hline CNA & car-none-above & 4 \\
\hline CGG & car-general-ground & 4 \\
\hline CGA & car-general-above & 5 \\
\hline CRG & car-reading-ground & 5 \\
\hline CRA & car-reading-above & 6 \\
\hline
\end{tabular}

\begin{tabular}{|c|c|c|c|}
\hline Mediacy Value & Transport mode & Information type & Elevation \\
\hline 2 & car & reading (art) & above \\
\hline 1 & bicycle & general & ground \\
\hline 0 & foot & none & - \\
\hline
\end{tabular}

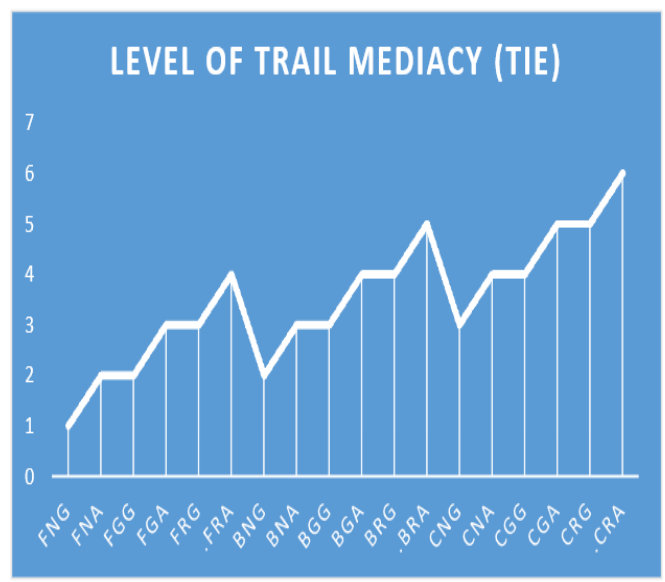

\section{Model of Trail Mediacy Parameters: transport mode, information type and elevation above ground (Data and Graph: Pahlen 2015)}

The model developed for estimating the levels of mediacy during the literary trail experience primarily focused on the mode of transport chosen $(\mathrm{T})$, the type

${ }^{3}$ While the Grey Street Writers trail did not make use of bicycles, this mode of transport has been included in the graph below to demonstrate that an intermediate level of mediacy can be achieved and emphasize the intersection between levels of mediacy on foot and by car. 
of information provided (I) and elevation (E) in relation to ground level, based on theoretical insights. The resulting cumulated value was called the Mediacy Value (M) of a specific stop on the trail. The model proves useful for the explanation of the dynamics of a trail's functions to further differentiate mediacy, extending the concept beyond the physical, to include social and mental forms of reconfiguring one's knowledge and definition of a place.

Moments of low mediacy enable first-hand insight into the socioeconomic importance of the way numerous (in-)formal networks function together and the specific sense of place. Moments of high mediacy provide room for reflection, informed by literature, historical facts or observant conversation. This theoretically allows for creativity and restructuring of preconceptions with what has just been experienced ${ }^{4}$.

\section{Analysis of the Grey Street Writers Trail}

To investigate the catalytic potential of the Grey Street Writers trail, the effect of modes of transport and the parameter of elevation in cultural practices will be examined with regard to its effect on participants. While the Grey Street Writers trail can itself be regarded as such an urban cultural practice, created and it is embedded in Durban's urban environment, the Casbah, itself teeming with cultural practices that provide contemporary points of reference for the trail's literary content, inspired by past specificities of the place. The map below provides an overview of the trail run.

Overall, the trail leads through the busiest parts of the Casbah, changing from car-based to pedestrian mode of travel. The majority of stops were covered on foot, with few readings in the midst of street-life. Most readings took place in the car, or generally in enclosed spaces where it was generally quieter and the group of around ten would be less of a disruption to businesses. In two cases the guide added a stop to the trail, to show what she perceived as relevant for a more balanced perception of the contemporary Casbah in relation to literature.

${ }^{4}$ Also see work by Joy Sather-Wagstaff 'Making Polysense of the world' in Heritage, Affect and Emotion: Politics, Practices and Infrastructures, 1/7/2016. 


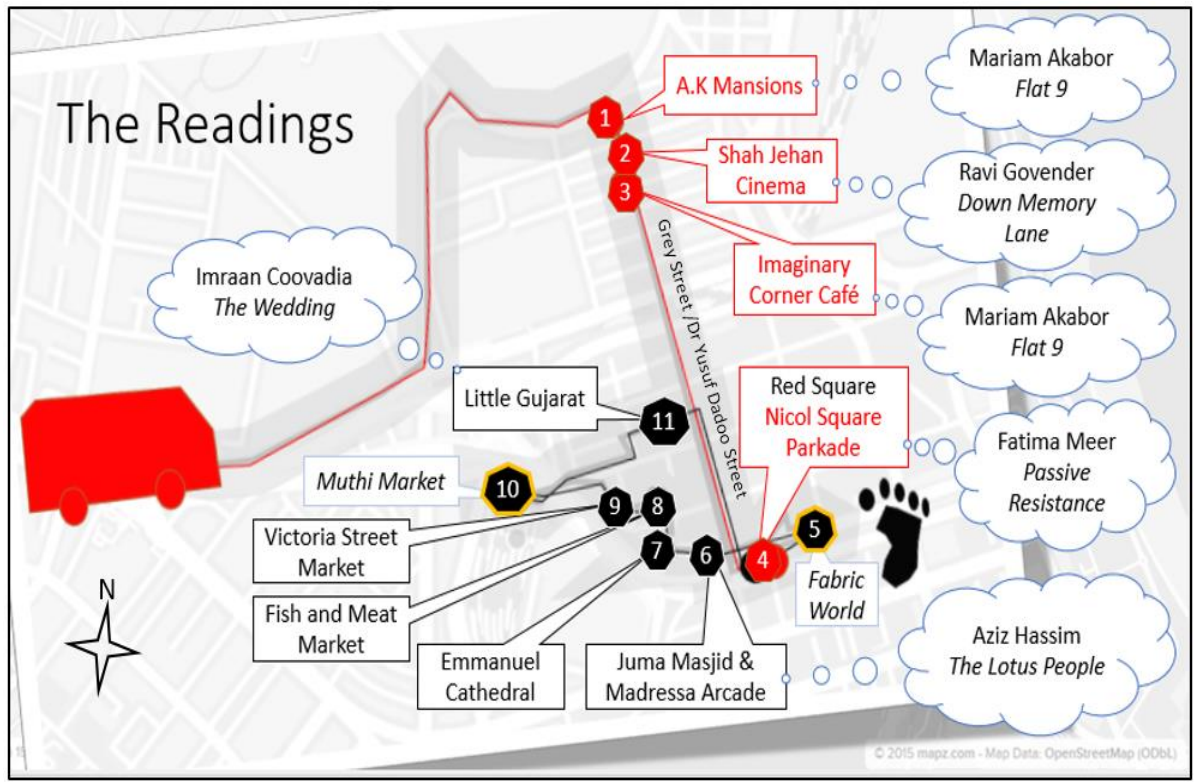

Grey Street Writers trail, July 2015 (Map: Mapz.com, OpenStreetMap. Trail visual: Pahlen)

The graph below offers the visualisation of the mediacy of the trail run ${ }^{5}$, followed by a detailed account of how these values were derived from the trail experience informed by theoretical considerations and examples from literature that informs the readings.

The beginning to the Grey Street Trail experience was in the main parking-lot of the Memorial Tower Building at the Howard College of the University of KwaZulu-Natal (FNG 1). Participants were greeted by Shiney Bright, the accredited guide. Ms Bright pointed out features of the trail on the pamphlet, especially the route that would be taken, referring to the map on the trail pamphlet and the writers (FGG2). The trail pamphlet follows the same design format as the others developed by KZN Literary Tourism: in appearance, the desired look is that of a book dustjacket with 'typewriter' lettering, running red dots like ellipses, further reading suggested on the back,

${ }^{5}$ The M-value in the graph is shown in red and black to differentiate the phases of the trail done on foot and within the car. 
a map of the stops, and contact details supplied plus sponsors' logos. The cover photograph of a Grey Street scene in the 1960s in sepia captures a bygone moment and signals both that this trail is a heritage project, and also that it is this version of Grey Street to which nearly all the selected writers nostalgically or otherwise return in their writing. The trail pamphlet is divided into three sections in common with all the other trails developed - short biographies of selected writers, a brief history of the area, and then places to visit on the walking tour.

\section{GREY STREET WRITERS TRAIL MEDIACY}

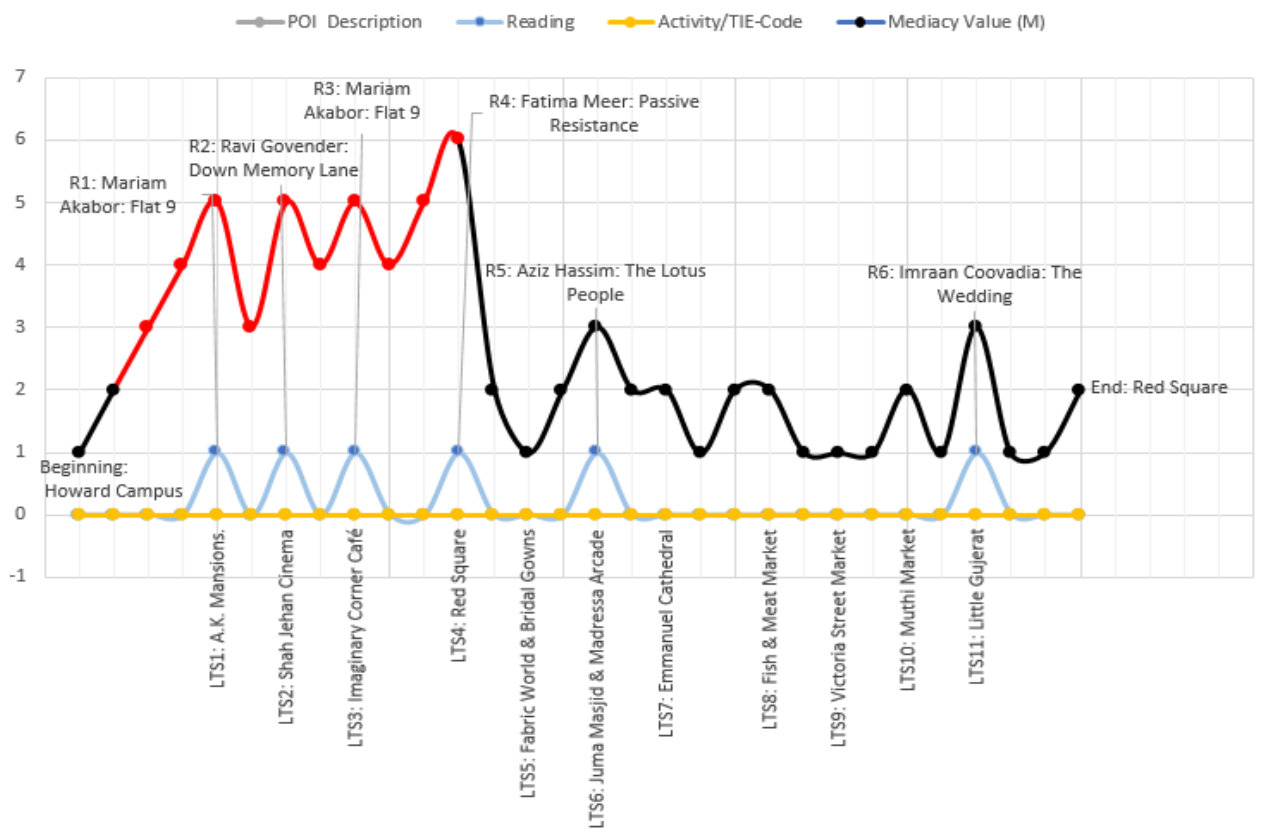

As the mode of transport changed from foot to car, the level of mediacy increased to (CNG 3), the lowest level of mediacy for the private transport. Public transport would have modified the level of mediacy as it would imply more direct contact with people going about their daily business and not part of the literary trail group, lowering mediacy to that of a pedestrian. The route taken from the university to Grey Street avoided the use of the fly-overs, 
driving along Old Dutch Road, ML Sultan Road, onto Mitchel Road and entering Dr Yusuf Dadoo Street (New name of Grey Street) from the north. The factor of elevation was low throughout this approach, and the general level of mediacy was CNG 3. On the way, Ms Bright drew attention to sites of interest, such as the ML Sultan College (DUT) and St. Anthony's Church, increasing the level of mediacy to CGG 4 at these points in time.

Turning into the northern end of Grey Street, the first stop was the former Thokoza Women's Hostel, where a brief introduction was made concerning the history of the hostel (CGG 4) and an excerpt of Mariam Akabor's novel Flat 9 was read with reference to A.K. Mansions as this part of Grey Street has a number of apartment buildings (CRG 5). At this and the next three stops, all participants and Ms Bright remained seated in the car. Between stops the level of mediacy dropped back to CNG 3.

The second stop was two streets down in front of the Methodist Church, looking at the building of the old Shah Jehan cinema, with a reading from Ravi Govender's Down Memory Lane relating to the Shah Jehan (CRG 5 ). The story was first contextualized by the history of the high number of cinemas in the area at one point and the outstanding recreational and social role they played (CGG 4). The contextualization increased mediacy to 4 , while the literature reading further increased it to 5 .

At the third stop, buildings of interest, such as the Indian Art Deco buildings and the characteristic colonnades of the buildings in the Grey Street area (CGG4) were pointed our and a reading given from Mariam Akabor's Flat 9 relating to the imaginary place of the corner shop café (CRG 5). From there the group was driven down Grey Street to the Nicol Square parkade. On the way, participants had time to speak amongst themselves, take pictures or ask questions relating to the streets, buildings and people they were seeing along Grey Street. Mediacy varied between 3 and 4.

Upon arriving at Nicol Square parkade, the mini-bus was driven to the second storey and parked on the western side, which offers an elevated view of Grey Street (CNA 4) and echoes observations by De Certeau of the ordering effect of perceiving the city from above. Remaining seated in the car, Ms Bright drew attention to the fact that the parkade stood on the site of what was dubbed 'Red Square', a site of numerous demonstrations against Apartheid legislation (CGA 5). Still seated in the car, an excerpt was read from Fatima Meer's book Passive Resistance related directly to Red Square, which increased mediacy to 6 (CRA), the highest level of mediacy. Similar accounts 
are given as the group proceeds on foot, the pause in readings and the change in transport lowering the general level of mediacy to FNG 2, still on the second level of the parkade. From the vantage point offered, the southern border of Grey Street was pointed out by Ms Bright, which passed south of the Nicol Square parkade. Attention was drawn to architectural features of buildings on either side of the parkade and the fact that arcades exist, allowing pedestrians to pass through the building blocks almost up to the railway tracks in the north of the Casbah, increasing mediacy to FGA 3. Street life, consisting of pedestrians and street vendors as much as flows of cars alternating with pedestrians at crossings could be observed and participants had a clear view of the Juma Masjid, the Ajmeri and Madressa Arcades, the Congress Hall, Emmanuel Cathedral as well as the fly-overs or bridges leading the highway into the central business district (FNA 2). At these occasions, the trail itself remembers the past and confronts the present, literally. Stops within sight of the Nicol Square parkade situated on the location of Red Square are landmarks of anti-apartheid struggle together with the Congress Hall bought by Gandhi and where the NIC held its meetings; the Madressa Arcade built in 1927 is still lined with little shops whose wares spill onto the pavement; and the Emmanuel Cathedral under the leadership of Denis Hurley. The Juma Mosque is described in The Lotus People as

... the magnificent and architecturally famous Juma Mosque, with its minarets and many domes ... it was a landmark for both the local residents and the out of town visitors. Adjoining the mosque, fronting on to Cathedral Road and directly opposite the historic Emmanuel Cathedral were a row of cottages that had been consolidated into a large unit that served as a madressah for Muslim children (168).

Such specific and intimate place-naming links to de Certeau's famous essay 'Walking in the City' (1984) already mentioned where he describes how it is not necessarily the city planners but the walkers of a city that 'give their shape to spaces. They weave places together'. So do all the writers of Grey Street - they describe in walker's detail their lives in Grey Street, crisscrossing roads, taking short cuts through alleys, weaving domestic patterns of familiarity. From Dr Goonam who remembers how ' $[\mathrm{t}] \mathrm{o}$ reach our schools, Tamil and English, we had to cross Grey Street, the one was in Cross Street, the other in Prince Edward Street... (1991: 14); to Phyllis Naidoo's specific 
address: 'The office of Phyllis Naidoo and Archie Gumede was on the seventh floor of CNR House, Cross Street, Durban' (2002: 18); to Coovadia's Ismet who 'wander[s] over to Queen Street, on the Field Street corner' to buy cigarettes (2001:161); to Akabor's characters Zohra Bibi and her servant Princess who 'walked into Ultra Fresh Grocers, which was situated on the corner of Grey Street and Fountain Lane' (2006: 47); all are mentally traversing and remembering lived spatial patterns in clear geographic detail over a period of many decades. By walking this area, the writers have got to know this place and therefore their own place in the world - this claiming of intimacy they pass on to their characters or their own histories. By repeating these patterns in writing about these same places, they retain their significance in the collective memory. Even the 'fictional' trail stops mentioned at the beginning of the trail are based on real places - the Corner Shop Café and AK Mansions in Akabor's Flat 9 are based on Haribol's Superette on the corner of Grey and Lorne Streets, and Afzal Building, 292 Grey Street respectively. This 'mini-India' of old Grey Street, though nowadays more multiracial, delapidated and less cohesive, provides the focus for the contemporary writers featured on the trail. By presenting their accounts, their significance in collective memory is potentially perpetuated and critically perceived through their juxtaposition with the contemporary experience. Here is Hassim on the Casbah:

In the late forties Grey Street, and the roads bisecting it, were a miniature replica of a major city in India. Rows of neat double-storied buildings consisting of stores on the ground floor and residential flats above, stretched from one end of the road to the other... The Casbah, as it was often referred to, was inhabited almost exclusively by Indians, with a fair sprinkling of coloureds. It was owned and developed in its entirety, and from its inception almost a hundred years before, by Indians who had automatically settled within its confines before spreading out into the suburbs. It was a vibrant and energetic community that was representative of the second and third generations of the early settlers (2002: 168-9).

And, Akabor on the sedimented layers of generational living in Grey Street: Uncle Imoo's café was situated at the corner of Grey and Lorne Street. 
His grandfather was the initial owner of the then tearoom a century ago. The Corner Café Shop was home to the many factory workers in the area; the housewives, especially the lazy ones who didn't feel like cooking; the school children who didn't like what their mothers packed them for lunch, as well as passers-by (2006: 14).

In essence, what is in operation here is what Middleton and Edwards call collective remembering; in their view 'collective remembering is essential to the identity and integrity of a community' (1990: 10). Boym, who differentiates between restorative (focus on nostos, return home) and reflective (focus on algia, the longing and loss) kinds of nostalgia, would term this reflective nostalgia. In Akabor there is a recognition that the time of Uncle Imoo's café is over, never to return, but in the detail with which she recalls the café lies the remembering, the reflective nostalgia:

'Remember the ole days? When Ma used to send us to Victoria Street market early in the morning to buy the freshest vegetables and fruit?' 'How Ossie always used to eat something on the way home!

Especially the fruit!' Everybody laughed. 'And how we used to watch movies in Shah Jehan every week? Do you know how your father used to like Dimple Kapadia? Everyone knew he watched Bobby more than ten times at the movies!' (2006: 103).

Such collective remembering by the contemporary writers mentioned above is important for establishing a sense of history and, above all, a sense of belonging to a place, even one now changed. Such belonging comes hard won after years of marginalisation by the apartheid government. Mamet observes how 'through fiction, Coovadia records and re-centres the collective memories of the old Indian diasporas, establishing counter-memories' (2008: 87) that resist earlier attempts at erasure. Even when Hassim in The Lotus People laments the changes in the area, that very act is an act of remembering and thus recovery:

The street's changing .... Look around you. There was a time you could spot half a dozen scotens with one sweep of your eyes. Not anymore. And the cinemas - the Vic, the Royal, the Avalon - all no more than a memory. What happened to Dhanjees Fruiterers, Victoria Furniture 
Mart, Kapitans, that noisy Royal Tinsmith Company ... hell, buddy, I could go on forever (2002: 511).

The roof of the Victoria Street Market can be seen from this vantage point distance, it is a re-creation of the original one destroyed by fire, whilst across the road is the fish market. The various markets of the area are a central focus of the writers, and trail. Walking down the narrow stairs of the parkade, the group was led through the arcade located on the ground floor and out the northern exit of the building towards the fifth stop on this trail, the Fabric World and Bridal Center (FNG 1). The process of changing mode of transit from car to walking and decreasing elevation changed the level of mediacy from 6 in the car, to 1 at the bottom of the stairs.

At this point of the trail, the main topics were Durban as a hub of the textile industry, the fact that all designs winning prizes at the fashion show of the Durban July, an international Horse Race held annually on the first weekend of July at Greyville Racecourse, were made of fabric bought in this shop (FGG 2).The group was given the opportunity to ask questions and explore the extensive selection of bridal gowns, fabrics and accessories (FNG $1)$.

The next stop was on the corner opposite the Juma Mosque, where Ms Bright drew attention to the fact that it was the first mosque on Grey Street, the biggest in Durban, and at one point, the biggest in South Africa (FGG 2). On the way to the crossing, the group was led half-way into two further arcades in the buildings opposite the Nicol Square parkade and introduced to a street vendor who was selling avocados, as well as oranges and bananas, and a selection of other items on the side of the pavement. Mediacy wavered between FNG 1 and FGG 2. After crossing the street, a reading was done at the entrance of the Madressa Arcade from Aziz Hassim's book The Lotus People, in which the character of this arcade during the 1950s-60s was described (FRG 3). No readings were done from this point forward until reaching the take-away restaurant Little Gujarat at the end of the trail.

Features of the current arcade were explained, especially the goods sold, such as the Lobola shop which sold items, including blankets, necessary in Zulu custom for negotiating the bride price (lobola). This held mediacy at a level of around 2 (FGG). Walking through the arcade, frequent stops were made to talk to shop owners and introduce the trail participants who were free to engage in light conversation with the shopkeepers, reducing mediacy to 1 
(FNG) for an extended period of time for those who did engage. Reaching the end of the Madressa Arcade, the group was taken into a shop selling meat and innards for a dish called Shisa Nyama, meaning grilled meat, explanations increasing mediacy (FGG 2).

Crossing the road, the group's attention was drawn to the Catholic Emmanuel Cathedral and the adjoining Dennis Hurley Center and the role played by Dennis Hurley in the resistance movements. Additionally, the peaceful coexistence and tradition of collaboration between church and mosque was emphasized along with the prevalence of charitable work done and the number of trusts in the area; level of mediacy remained at FGG 2. After going inside the Cathedral, the group walked back out of the compound and across Dennis Hurley Street into the Fish and Meat Market, decreasing mediacy to FNG 1. Before going into the market, attention was drawn toward the Mahatma Ghandi Library, which housed a substantial amount of law books before they were moved to Howard College and provided unique access to these books and an adequate study area to many African law students during Apartheid; level of mediacy increased to FGG 2.

Inside the Fish and Meat Market a small selection of fish could be seen, numerous stalls were empty but anything from chicken, sheep's heads and washed or unwashed innards could be bought, which provided participants sufficient material to talk about, and represents a low level of mediacy between FNG 1 to FGG 2 due to the intensity of attention and direct engagement with the environment being walked through. From the Fish and Meat Market the group passed by a fruit vendor, where Ms Bright bought some bananas, which she offered to the group to try (FNG 1).

In Victoria Street market, the first stop was a spice shop, where the owner introduced the group to his knowledge on the properties, uses, quality and price of spices available. As this meant direct interaction with the shopkeeper, the level of mediacy was very low, at $F G G 1$, because the porosity of FGG 2 increased dramatically due to a change in narrator from guide to shopkeeper for the duration of the visit to the spice shop.

The group then proceeded along the passages of the indoor-market, again being introduced to selected shop owners, making time for some smalltalk between trail participants and the shopkeepers (FNG 1). While the market has two levels and is rather extensive, only a part of the ground floor was visited. The group was led out the back and down a few steps and past stalls selling diverse utensils for administering traditional African medicine that 
could be bought in neighbouring stalls, which gave further opportunity to talk about what could be seen and how it was used within the group (FNG 1).

The path of the trail now departed from the route set down on the trail pamphlet. This decision by the guide shows the agency that influences the delivery of the trail design, and alters the experience of the literary trail by including contemporary features that do not prominently feature in selected writings. The group crossed a busy street to the Bridge Market, commonly referred to as the Muthi Market (FNG 1), which is stop 10 on the trail map. Here, the vast variety of parts of indigenous plants and animals was on display, all constituting part of the pharmacy of traditional African medicine. Walking through the market, Ms Bright encouraged the group to always greet the people encountered in Zulu, as a sign of respect. She also pointed out and asked about various plants and some uses (FGG 1-2). At the top end of the bridge, the group could see part of the Early Morning Market and were informed of its history (FGG 2), but did not cross over the foot bridge. Instead, the group turned around and proceeded to the Music Bridge adjoining the Herb Market, under the bridge and out back across the road past the Victoria Street Market (FNG 1). Ms Bright mentioned further markets that take place in the area at different days of the week, such as the Bead Market (FGG 2). One could argue that the additional experience balances the selected literary depictions of the area.

The rest of the route took the group through some alleyways characterized by refurbished art deco house facades and onto Dr Goonam Street to Little Gujarat restaurant - food being the great carrier of diaspora, culture and 'home' that it is the world over. On arriving in Durban, Ismet and Khateja from The Wedding

for four days ... lived on bunny chows from the café on Victoria Street: loaves with their insides scooped out and replaced with a steaming dollop of curry, meat, fat butter beans, and potato coins (2001: 157).

At this old established and always busy eatery, tired literary tourists can try out a bunny chow, a Durban adaptation of 'curry to go'. In the restaurant the group, as in the novel, is provided with an opportunity to sample an assortment of Indian food, ranging from chili bites to samoosa and more vegetarian delicacies, and provided with refreshments. The reading given at this last stop (11) was from Imraan Coovadias novel The Wedding, in which food is of major importance, for handling marriage discord. The level of mediacy increased to 


\section{Bettina Pahlen \& Lindy Stiebel}

FRG 3 during the reading, quickly returning to (FNG 1) as participants sampled the food. This is an apt end to the trail: the bunny chow, after all, is a potent reminder of people who came from afar, who stayed on and adapted to local conditions, and who wrote about a place called Grey Street.. The level of mediacy was continually low, between 1 and 2, implying high levels of interaction, exposure and proximity at ground level during this time. After this stop, the group was led past the construction site of the Ghandi Museum, onto Grey Street and back to Nicol Square parkade (FNG 1), where the Grey Street Writers trail ended (FNA 2).

This extensive analysis shows how the literary trail may be considered a frame narrative, both physically and on the level of content, into which literature and history related to the Grey Street Casbah are embedded. A narrative consists of story, plot and discourse. Trails have a strong physical mode of emplotment, localizing and positioning themselves and embedded stories within a concrete time/space relation via the physical path or pattern of movement of actors (guide and participants) through a geographic location (cf. Wrana 2014: 298-299). The trail's activities, such as walking and driving, performing readings, or interacting socially, are used to facilitate the sequence of events on the trail, but can also be understood as tools of emplotment, as much as speech, as they bear the potential to influence what is perceived as causally or logically connected sequence of events.

Sensory exposure to the Casbah and its street life proceeded sensitively on the Trail, beginning with a high level of mediacy (from the car to walking). This allowed some time to grow accustomed to the initially overwhelming street life as the level of mediacy decreases and then alternates, following the careful combination and sequencing of works of Grey Street writers, history and knowledge of architecture and, most importantly, the encounters with the people along the trail and the stories they have to tell.

To interpret the graph, increasing the level of differentiation of mediacy to describe social mediacy in addition to the physical might be helpful. In one case, where a shopkeeper succeeded in decreasing the level of mediacy (see Victoria Street Market LTS 9) without physical proximity increasing. In comparison to explanations by the guide, who is perceived by group members to belong to the social entity of the trail group and therefore less to the surrounding social fabric, the explanations provided by shopkeepers or vendors allowed for immersion in the social context beyond the group through verbal exchanges. Initially, the group was, 'extended' or 'opened' by introduction to 
the social context of the shop owner, facilitating direct social exchange between the group and a member of the social context, which can be described as social immersion, or a greater amount of social immediacy. It cannot be described as physical immediacy, since no substantial amount of physical proximity was increased, except perhaps in the case of persons buying spices in the end. However, proximity in terms of social affiliation is of a different quality to physical proximity (family members communicating via an online communication platform may physically be hundreds of kilometres away), and social mediacy is a question of whether the person giving information primarily belongs to the social group of the trail, or that of the context of the trail, where people providing information are not paid by participants, guide or the project for their contribution.

In theoretical terms, literary trails make skilful use of effects of depragmatization afforded by literary works. A level of

depragmatization: i.e. [...] the suspension of direct referentiality and immediate purpose [of stories told], [...] enables the aestheticising distancing of real-world experiences and at the same time makes possible their imaginative exploration (Zapf 2001 in Grabes 2001: 87).

Stories told during the literary trails are metaphors, abstracted versions or reallife experiences with which to reassess real-world experiences. The partially fictive nature of places featured in writing (e.g. the imaginary corner café in Mariam Akabor's Flat 9) highlights the constructedness of both the trail and the perceived context, and draws attention to the actual process of perception, the limits of its reliability and the malleability of 'reality'. This can be a slightly unsettling experience. Varying degrees of unsettling experiences facilitate, or inhibit, the receptiveness to new discourses, lines of argumentation and insights previously disregarded. The pauses in narration with opportunity for unmediated exploration, as much as the suspension of direct reference to reality, are also key to preventing the immediate dismissal of new concepts. It encourages the imagination of an individual to actively look for parallels in personal experience and reconnect 'abstract cultural realities to concrete life processes' (Ibid 88) thus building a structure of reasoning that increases the degree of acceptability of this new piece of information.

Trail runs are of temporary physical existence compared to the relative duration of existence of historical buildings, sites, and the knowledge and 
stories that may be associated with them. The latter two may remain transitive until 'fixed' in media, and still, may not be perceived to be associated with physical structures one may pass everyday. Literary trails provide this combination, going beyond the historical by the reading of a selection of short, literary narrative plots directly associated with the physical environment, intermittently at specific locations along the trail. Literary heritage and physical context serve as mutual anchors of memory and as mutual amplifiers of (actually or creatively) associated urban imaginaries and experiences.

The Grey Street Writers trail itself exhibits literary functions mentioned in Hubert Zapf's theory of literature as cultural ecology. Mediation of these experiences through a guide potentially enables a rational processing of the experiences. This transformative creative process catalysed by the Grey Street Writers trail is potent if the abstractions recognizably represent repressed discourses, by which the trail gains a re-integrative function. Further, if it represents and critically balances 'typical deficits, contradictions and deformations in prevailing political, economic, ideological and utilitarian systems of civilisatory power' (Zapf 2001 in Grabes 2001: 93) by which the trail provides a cultural-critical metadiscourse. Moreover, if prevailing systems of power are confronted with abstract cultural realities that add further categories 'to the available cultural self-interpretation' in the form of 'a holistic-pluralistic approach that focuses specifically on [what is] marginalized, neglected or repressed by these systemic realities, and articulates what otherwise remains unarticulated' (Ibid) by its choice of literature, for example, the trail expands the extent of what can be imagined possible within a given cultural context, thereby engaging in an imaginative counter-discourse.

\section{Reception of the Grey Street Writers Trail}

Key to the success of literary trails with diverse audiences (not all participants are literary enthusiasts) is that the level of mediacy alternates between high and low levels. Low levels are characterized by direct interaction with the built environment in the midst of street life during a physical walk through the city. The phases of higher mediacy allow time for reflection to take place, necessary for learning/transformation processes, as well as lower mediacy for phases of exploration and engagement to test new attitudes. The chronology and type of information, the balance between mediacy and immediacy, as well as the 
character of the organized randomness of street life encountered during the trail experience are paramount to the success of the mental restructuring process. These factors can be influenced by the trail design and the guide only to a certain extent. A plethora of actions by urban practitioners in urban regeneration and the general public, which construct the trail's physical and social context as perceived by trail participants, lie outside the influence of trail designers. This highlights the high degree of dependence of a trail's effect on its socio-spatial context.

Even though half seldom visit the Casbah due to more convenient access to services close to their homes, most participants saw no reason to avoid the area. Participants visit this part of the city mainly for the food found there, the taxi rank and the inner city as a destination in itself. For those who did mention avoiding the area prior to doing the trail, as much as for those familiar with it, the literary trail facilitated new, exciting and perceptionchanging experiences. It also reminded participants of childhood memories and family connections to the socio-economic fabric around Grey Street. This shows that the literary trail had a profound effect on participants with a high level of prior knowledge of the area, as much as on participants with little prior knowledge of this part of the city. In one case, this knowledge came from stories shared within their family about experiences of the markets of Grey Street and Warwick in the past. In another case, it derived from personal experience of everyday life in the markets, due to family relations to traders. These insights were shared on location between members of the trail participants during conversation. Both indicate a deep understanding of the place. The level of emotional attachment to the area is high in both cases, indicating that the economy of Grey Street area impacts on the lives, families and histories and memories of people in Durban, and that changes in Grey Street reach further than the actual traders in the area, into vast socio-economic networks in various localities across the city.

Highlights of the trail were said to be the interactions with people, the local food, followed closely by the readings and history provided. Half the participants suggested visiting the interior of the Juma Masjid and providing more readings. While some continued to regard the Muthi market critically, most considered it to be mainly an economic cornerstone of the area after the trail. The Juma Mosque and the Emmanuel Cathedral are perceived as an unusual example of mutual support between Muslims and Christians in current everyday life, as well as being fine examples of cultural heritage architecture. 
Together with the markets of Warwick, Victoria Street Market, Madressa Arcade and the colonnades of the buildings along Grey Street/Dr Yusuf Dadoo Street, the Mosque and Cathedral were deemed most important for the unique (in)formal African-Indian character of the Casbah after the trail.

One participant refers directly to an experience resulting from a low level of social mediacy and direct interaction with shopkeepers along the trail, suggesting that this social grouping is as important to the trail experience as the readings, allowing insight into the 'lives and perspectives' (cf. Questionnaire T4) of today's shopkeepers and residents. At this point, the facilitating role of the trail guide bridged the social distance between members of the group and shop owners or street vendors. Even if participants may pass street vendors in very close proximity, the social distance might still be enormous and communication based solely on the intention to buy/sell something. Shopkeepers along the Madressa Arcade as well as in the Victoria Street market observed that safety is the single most important factor for the viability of business on Grey Street, given the dependence of shops on pedestrians and tourists.

The perception of safety within the Casbah after the trail run was surprisingly shown not to correlate necessarily with perceived cleanliness, the reputation or noisiness of the place. A participant, largely unfamiliar with the area, remarked,

It was wonderful to feel part of the buzz of an urban, cosmopolitan African inner city. I would not normally enter this area on my own due to fears of being mugged. I now realise that it is safer and friendlier than I originally thought. I particularly enjoyed the way the guide read from the texts by the Grey Street writers - it gave a sense of the spirit of the place both past and present (Questionnaire T2).

Statements highlight the potential to address the fear of entering certain physical and social urban spaces and changing it into a sense of familiarity through the literary trail. It might also indicate that participants recognized the irrationality of their fear in a guided group context, resulting in a positive literary trail experience. The fact that 'feeling part of the buzz' and 'safer than originally thought' is mentioned by this participant may indicate the trail was successful in providing enough room for positive mutual experiences in the 
regenerating environment, resulting in a small change of attitude, and perhaps a more balanced sense of place.

In effect, the Grey Street Writers trail is a complex form of cultural production creating alternating levels of mediacy. The factors influencing the levels of mediacy are purposefully combined to form a highly mediated, yet perpetually unique trail experience for each individual. The questions of 'who' delivers what kind of information, in which setting, and with which type of transport is crucial for modifying the levels of mediacy by design. Perceived levels of mediacy can differ from person to person depending on their specific interests and attention spans.

\section{Limits of Influence}

The literary trail itself intentionally impacts on the area physically, socially and economically to a small extent, due to the subsistence approach to running the trail (run on demand, not for profit, just to cover costs) and is not marketed aggressively. Any added economic impact depends on the willingness of trail participants to spend their money in the Casbah. The core advantage of the academic nature of the trail is its contribution to preserving the everyday routines of the Grey Street Casbah. Based on its dynamic resilience over the past decade and renewed interest in the Grey Street Writers trail, it will probably continue to exist in the future.

Urban regeneration is a determining factor for the existence of the trail in the future. Amongst other factors, its continued success will depend very much on decisions made to develop the inner city and especially the markets of Warwick and the Grey Street area. A higher frequency of literary heritage trail runs could potentially change the urban fabric into a tourist-dominated place, at the loss of its current character. At the time of writing, a certain degree of this might temporarily be beneficial for businesses currently relying on tourists visiting the currently regenerating area, but is something that needs to be monitored.

New impressions can be overwhelming and need to be processed. Especially in initial social contact situations on the trail, having time and space to retreat from the attention or direct engagement with people and place is crucial. The mode of transport used to approach Grey Street was attuned to the dominant sequence of transport use, beginning with a mini-bus (though private, 
which is a different experience to the public taxi) and transitioning to pedestrian movement through the city. A potential of the literary trail open to discussion might lie in introducing trail participants to the use of the regular mini-bus taxis, a form of public transport, the experience of which was a topic of conversation between trail participants. However, according to the guide, the logistics of moving a tour group dictate a reliable mode of transport, insurance held by the driver to transport tourists and a set time.

The trail run showed the potential of involving shopkeepers and vendors in the storytelling, as previously sceptical participants of the trail echoed shop owners by the end, who observed that the area is currently safer than generally thought. Augmenting interactive properties of the maps provided on the website, the accessibility of the site and authors works for people with visual impairment and auditory comprehension skills, and perhaps expanding the use of languages could increase the audiences reached.

The engagement of the context of the trail, in terms of shopkeepers and institutions along the trail, in the running of the trail might be a better way to perpetuate the trail's existence. Informing about how the trade and service networks function in daily life creates a more critical understanding of the place perceived by trail participants during these phases of lowest mediacy. This is achieved to some extent through the guide's decision to pause readings until Little Gujarat and instead picking up on what participants point out within the group and drawing attention to observable cultural symbols, such as the dress of traditional healers that demand extra information to be noticed and interpreted by a newcomer to the place. An experimental area of thought alludes to the implementation of the Grey Street Writers trail to augment lawfocused induction programmes for stakeholders directly involved in changing the urban fabric.

Architect Jonathan Edkins aims to make the Grey Street Writers trail a fixture in an architecture course he runs at the Durban University of Technology dubbed 'Happitecture', expanding the influence of the trail to people who will influence the face of the city to a large extent. According to Edkins, the trail provides a combination of mediacy, exposure to the immediate surroundings of Grey Street and access to both history and literature suited to filling a gap in the programme. A most important feature of the literary trail is that functions of literature are imported into the trail experience. This sets the Grey Street Writers trail apart from other heritage trails. One might consider making use of other forms of art that might have similar effects, but for the 
purposes of this trail, the fact that readings can take place in situ brings the place to life, not only in the present day but in the historic past as perceived with memories of the trail experience in the pages of the book. The course challenges architects to think past just the built structure of the city.

Altogether, the Grey Street Writers trail may foster a deeper understanding of the Casbah's socio-economic and cultural urban fabric, thereby counter-balancing rumour and showing the effect of what Edward Relph describes as a balanced sense of place. The trail, when run, may contribute to better informed decisions regarding Durban's literary and cultural heritage when considering economic and infrastructure projects, ideally creating an awareness for the palpable history and significance of the Grey Street area, beyond Durban.

\section{Conclusion}

The place-making capacity of the Grey Street Writers trail is an effective tool that can contribute to reconfiguring the Casbah's reputation alongside ongoing regeneration projects and trails. The prerequisites are largely given. Success of regeneration efforts in connection with the guided group situation of the Grey Street Writers trail provides the parameters needed to create a basic sense of security required for such a process to be initiated. Research into the behaviour of the trail's design demonstrated its potential for addressing fears of entering the place or meeting people working and living there, due largely to the reputation of the precinct. The mediated experience, provided in a guided group setting by car and on foot, allowed insights into places that may previously thought to be out of bounds, not entirely known, or purely imaginary. The dynamic of alternately increasing and decreasing the layers of mediacy is key to understanding the success of the trail in changing ingrained perceptions of an area by preventing the immediate dismissal of new, unfamiliar impressions or concepts. This leads to the conclusion that Grey Street Writers trail has the potential to balance and transform negatively preformed imaginaries associated with the area into a sense of familiarity, homeliness and safety in light of progress made to dynamically stabilize the literary trail's context, that is the socio-economic ecology of the greater Warwick Junction Precinct. 


\section{References}

Akabor, M. 2006. Flat 9. Durban: umSinsi Press.

Bridge, G. \& S. Watson (eds.) 2002. The Blackwell City Reader. Malden, MA: Blackwell.

Bucksch, J. \& S. Schneider 2014. Walkability: Das Handbuch zur Bewegungsförderung in der Kommune. Bern: H. Huber.

Butler, M. \& J.M. Gurr 2014. Urbane Populärkultur als Bewertungspraxis und -ressource: Zum normativen Potential populärkultureller Inszenierung und zur diskursiven Aneignung urbaner Räume. Place-Making in urbanen Diskursen. Berlin: De Gruyter.

Coovadia, I. 2001. The Wedding. New York: Picador.

Cuddon, J.A. \& C.E. Preston 1999. The Penguin Dictionary of Literary Terms and Literary Theory. $4^{\text {th }}$ Edition. London: Penguin.

Goonam, K. 1991. Coolie Doctor: An Autobiography. Johannesburg: Madiba Publications.

Grabes, H. (ed.) 2001. Literary History - Cultural History: Force Fields and Tensions. Tübingen: Narr.

Gunning, S. \& P. Machen (eds.) 2014. Durban Architecture Guide. Durban: City Architects Department eThekwini Municipality.

Gurr, J.M. 2010. Urbanity, Urban Culture and the European Metropolis. In Szeczekall, M. (ed.): Britannien und Europa - Studien zu Literatur-

Geistes- und Kulturgeschichte. Festschrift für Jürgen Klein. Frankfurt/ Main: Lang.

Haferburg, C et al. 2014. Post-World Cup Effects and Local Regeneration Strategies in Johannesburg and eThekwini. In Haferburg, C. \& M. Huchzermeyer (eds.): Urban Governance in Post-apartheid Cities: Modes of Engagement in South Africa's Metropoles. Stuttgart: Borntraeger.

Haferburg, C. and Huchzermeyer, M. (eds.) 2014. Urban Governance in Postapartheid Cities: Modes of Engagement in South Africa's Metropoles. Stuttgart: Borntraeger.

Hassim, A. The Lotus People. Johannesburg: STE Publishers.

Mann, L. 1997. Sozialpsychologie. 11 $1^{\text {th }}$ Edition. Weinheim: Psychologie Verlags Union.

Mamet, C. 2008. Re-constructing Grey Street in Imraan Coovadia's The Wedding. Alternation 15,2:71-90.

Meyer, M. 2008. English and American Literatures. Tübingen: Francke. 
Middleton, D. \& D. Edwards 1990. Collective Remembering. London and New Delhi: Sage.

Northrup, D. 1993. Indentured Labor in the Age of Imperialism, 1834-1922. Cambridge: Cambridge UP. Available at: https://archive.org/stream/ indenturedlabori00nort/indenturedlabori00nort_djvu.txt. (Accessed on 29 August 2015.)

Project for Public Spaces 2015. Available at: http://www.pps.org/reference/ what_is_placemaking/. (Accessed on 06 August 2015.)

Project for Public Spaces 2015. Available at: http://www.pps.org/ reference/11steps/. (Accessed on 06 August 2015.)

Rosenberg, L. et al. 2013. The Making of Place: The Warwick Junction Precinct, 1870s-1980s. Durban, South Africa: Durban University of Technology.

Smith, D.M. (ed.) 1992. The Apartheid City and Beyond: Urbanization and Social Change in South Africa. London, New York, Johannesburg: Witwatersrand University Press.

Stiebel, L. 2004. Hitting the Hot Spots: Literary Tourism as a Research Field with Particular Reference to KwaZulu-Natal, South Africa. Critical Arts 18,2: 31-44.

Stiebel, L. 2009. Going on (Literary) Pilgrimage: Constructing the Rider Haggard Literary Trail. In Watson, N. (ed.): Literary Tourism in Nineteenth Century Culture. London: Palgrave.

Stiebel, L. 2010. Last Stop Little Gujerat: Tracking South African Indian Writers on the Grey Street Writers' Trail in Durban. Current Writing 22,1:1-22.

Stufflebeam, D.L. \& C.L.S. Coryn 2011. Evaluation Theory, Models \& Applications. $2^{\text {nd }}$ Edition. San Francisco, CA: Jossey-Bass, A Wiley Brand.

Szeczekall, M. (ed.) 2010. Britannien und Europa - Studien zu LiteraturGeistes- und Kulturgeschichte. Festschrift für Jürgen Klein.. Frankfurt/ Main: Lang.

Throgmorton, J.A. 2003. Planning as Persuasive Storytelling in a Global-Scale Web of Relationships. Planning Theory 2:125..

van Hulst, M.J. 2012. Storytelling: A Model of and a Model for Planning. Planning Theory 11:229.

Wrana, D. et al (eds.) 2014. DiskursNetz: Wörterbuch der interdisziplinären Diskursforschung. Berlin: Suhrkamp. 
Zapf, H. 2001. Literature as Cultural Ecology: Notes towards a Functional Theory of Imaginative Texts with Examples from American Literature. In Grabes, H. (ed.): Literary History - Cultural History: Force Fields and Tensions. Tübingen: Narr.

\section{Interview References}

Interview Stiebel, L. 2015 in Pahlen, B. Literary Trails in the Context of Urban Regeneration: Case Study of the Grey Street Writers Trail in Durban. Unpublished Masters Thesis.

Interview Edkins, J. 2015 in Pahlen, B. Literary Trails in the Context of Urban Regeneration: Case Study of the Grey Street Writers Trail in Durban. Unpublished Masters Thesis

Interview Notes Rosenberg L. 2015. Please Contact Bettina Pahlen (bpahlen[at]web.de).

Interviews Madressa Arcade 2015. Please Contact Bettina Pahlen (bpahlen[at]web.de).

Bettina Pahlen University of Duisburg-Essen Germany bpahlen@web.de

Lindy Stiebel University of KwaZulu-Natal South Africa stiebell@ukzn.co.za 